\title{
VERTEBRAL OSTEOMYELITIS IN ADULT PATIENTS - CHARACTERISTICS AND OUTCOME
}

\author{
Matej Mustapić ${ }^{1}$, Klaudija Višković ${ }^{\text {, Igor Borić }}{ }^{3}$, Domagoj Marjan ${ }^{1}$, Dijana Zadravec ${ }^{1}$ \\ and Josip Begovac ${ }^{4}$
}

\begin{abstract}
${ }^{1}$ Department of Diagnostic and Interventional Radiology, Sestre milosrdnice University Hospital Center; ${ }^{2}$ Department of Radiology and Ultrasound, Dr Fran Mihaljević University Hospital for Infectious Diseases, Zagreb; ${ }^{3}$ Department of Radiology, Sveta Katarina Special Hospital, Zabok; ${ }^{4}$ Dr Fran Mihaljević University Hospital for Infectious Diseases, Zagreb, Croatia
\end{abstract}

\begin{abstract}
SUMMARY - The aim of the study was to assess disease characteristics and outcome in patients with vertebral osteomyelitis (VO). A two medical centre retrospective cohort study was performed by chart review after discharge of 110 patients with confirmed VO treated during a 5-year period. Patients were divided in two groups: patients with uncomplicated $\mathrm{VO}$ and patients with complicated VO. All patients underwent clinical and biological examinations and magnetic resonance imaging (MRI) according to the same protocol. Patients with complicated VO were significantly older $(\mathrm{p}=0.038)$. They were longer treated with antibiotics parenterally $(\mathrm{p}=0.047)$ and more often surgically $(\mathrm{p}<0.001)$. In these patients, high Charlson comorbidity index (CCI) score was more often observed ( $p=0.024)$, as well as liver cirrhosis $(p=0.013)$ and degenerative spine disease $(p=0.007)$ as comorbidities. Patients with advanced MRI changes of VO had a modified CCI score of 2 or more $(p=0.006)$. They more often experienced neurological deficit $(p=0.021)$. Staphylococcus aureus was the most frequently isolated bacterium from blood and tissue samples. Advanced MRI changes and complicated $\mathrm{VO}$ were more often observed in patients with high CCI score due to impaired immune system caused by chronic comorbid disease(s) or modulation of immunity with medications. High CCI scores were more frequently associated with positive blood cultures due to bacteremia because of impaired immunity. Patients with complicated VO were longer treated with antibiotics parenterally and more often surgically treated for phlegmon and abscess formation. Liver cirrhosis and degenerative spine disease, which were more often found in patients with complicated VO, obviously impacted the course of the disease.
\end{abstract}

Key words: Osteomyelitis, spine; Magnetic resonance imaging; Comorbidity; Outcome assessment; Adult

\section{Introduction}

Vertebral osteomyelitis (VO) accounts for 2\%-4\% of bone and joint infections. The incidence of $\mathrm{VO}$ seems to be increasing because of higher life expectancy in older patients with serious comorbidities and increase of spinal surgery, as well as other invasive

\footnotetext{
Correspondence to: Matej Mustapic, $M D, P h D$, Department of Diagnostic and Interventional Radiology, Sestre milosrdnice UniversityHospitalCenter, Vinogradskac. 29, HR-10000Zagreb, Croatia E-mail:mmustapicm@gmail.com

Received June 9, 2015, accepted August 14, 2015
}

procedures resulting in bacteremia. The most frequent comorbidities in these patients are diabetes mellitus, immunodeficiencies and malignancies ${ }^{2,3}$. Pain is the commonest symptom of early VO while fever may not be present (frequency varies from $35 \%$ to $60 \%)^{4}$. Neurological symptoms, such as numbness, weakness or radiculopathy, are present in about one-third of patients ${ }^{5}$. The most common bacterial pathogen is Staphylococcus aureus with an incidence between 30\% and $80 \%{ }^{6}$. Mortality is attributable in part to comorbidities and ranges from $2 \%$ to $30 \%{ }^{1,7}$. 
Magnetic resonance imaging (MRI) is by far the most valuable imaging procedure for early diagnosis and follow-up of patients with osteomyelitis including $\mathrm{VO}^{7-9}$. MRI with a paramagnetic contrast medium and fat suppression techniques shows sensitivity similar to scintigraphy (96\%) and specificity equal to computed tomography (CT) $(93 \%)^{10}$. The Charlson comorbidity index $(\mathrm{CCI})$ is a method of predicting mortality by classifying or weighting comorbid conditions ${ }^{11}$. To measure disease burden, Charlson et al. assigned a weighted score to each comorbid condition based on the relative risk of 1-year mortality ${ }^{11}$. A mong many potential comorbidity variables assessed, 17 were found to be associated with 1-year mortality. Quan et al. updated the CCI based on the hazard ratios of individual comorbidities for mortality within 1 year after hospital admission ${ }^{12}$.

The aim of this study was to assess disease characteristics and outcome in patients with VO. There are no specific studies in which MRI findings and CCI score were observed in patients with VO.

\section{Materials and Methods}

\section{Study design}

A two-centre, retrospective analysis included consecutive adult ( $\geq 18$ years of age) patients treated for definite VO between January 1, 2006 and December 31, 2011 at Dr Fran Mihaljević University Hospital for Infectious Diseases and Sestre milosrdnice University Hospital Center in Zagreb. During this period, all patients suspected of having $\mathrm{VO}$ underwent the same standardized in-house protocol with detailed prospective data recording.

For the purpose of the study, the hospital electronic database and source data were searched independently by two investigators to identify qualifying patients and to double-check the extracted data. All the patients had MRI of the spine and all the images were reviewed by two senior musculoskeletal radiologists who were blind to clinical data. The study was approved by the institutions' Ethics Committees.

\section{Patients}

Vertebral osteomyelitis was diagnosed based on clinical presentation (unremitting back or neck pain, presence of fever $\geq 38.1{ }^{\circ} \mathrm{C}$, and neurological deficits) and supportive MRI findings (we observed: initial MRI findings - vertebral body edema and discitis; and advanced MRI findings - height reduction of the intervertebral disc, vertebral body endplate erosions, compression fracture and intraosseous, paravertebral or epidural abscesses).

Out of the total of 239 adults with VO treated during the observed period, the present analysis embraced 110 patients (54.5\% males and $45.5 \%$ females). Exclusions were due to MRI examination performed by different protocols, and vertebral lesions due to primary or secondary bone tumors and proved tuberculous, parasitic or fungal etiology.

\section{Magnetic resonance imaging}

Magnetic resonance imaging was done using a Siemens Avanto 1.5 T scanner (Siemens, Erlangen, Germany) performing routine imaging techniques including contrast-enhanced T1-weighted images (WI) in axial, coronal and sagittal plane. A paramagnetic contrast agent gadopentetate dimeglumine (Magnevist, Schering, Berlin, Germany) was used in a dose of $0.1 \mathrm{mmol} / \mathrm{kg}$.

\section{Treatment}

Initial empirical antibiotic treatment recommended by the Hospital Drugs Committee was followed by, when applicable, a bacteriologically targeted treatment in overall duration of six to eight weeks. In a significant proportion of patients, surgical intervention was needed because of complications (formation of abscesses, bone destruction and spine instability compromising neural structures).

\section{Comorbidities}

Underlying medical conditions (comorbidities) were scored through the modified CCI and stratified in two groups according to the CCI score: low (0-1) or high $(\geq 2)^{2,12,13}$. Serious comorbidity includes immunodeficiency (due to immunosuppressants, HIV infection or splenectomy, diabetes mellitus and malignancy), major rheumatic inflammatory diseases of the spine (rheumatoid arthritis, psoriatic arthritis and ankylosing spondylitis), degenerative spine diseases and other chronic organ diseases (alcohol abuse or cirrhosis, endocrine disease except for diabetes mellitus, and chronic heart, lung, kidney or liver disease). 


\section{Disease outcome}

We divided patients into two groups: patients with uncomplicated VO and patients with complicated VO. Complicated VO implies the following: 1) need for surgical intervention; 2) incomplete recovery with residual motor weakness or paralysis or pain that limits activity after completion of antimicrobial treatment; 3) interruption of antibiotic therapy before three months of duration on patient's demand with residual motor weakness or paralysis or pain that limits activity; and 4) death.

\section{Data analysis}

Data were summarized for the entire cohort and also separately for the patients with uncomplicated $\mathrm{VO}$ and complicated VO. We computed frequencies for categorical variables and medians and interquartile ranges (IQR) for nonnormally distributed continuous variables. To compare different characteristics of patients with low and those with high CCI score, we used Whitney-Mann test for continuous variables and Fisher's exact test or $\chi^{2}$-test for categorical variables. All statistical tests were two-tailed, and a $\mathrm{p}$ value of $<0.05$ was considered to be statistically significant. Statistical analyses were performed using the Statistical Product and Service Solutions (SPSS) software version 13 (SPSS Inc., Chicago, IL, USA).

\section{Results}

\section{Patient and disease characteristics}

A total of 239 patients with $\mathrm{VO}$ were identified during the study period and 110 patients were included in the study. The median patient age was 59.5 years. Most patients experienced pain and had fever, and onethird of patients had neurological complications $(92 \%, 59 \%$ and $36 \%$, respectively). Patients with complicated VO were significantly older (median age 62.5 vs. 55.0 years, $\mathrm{p}=0.038$ ) and more often experienced neurological deficit $(\mathrm{p}=0.021)$. Spinal infection was most frequently located in the lumbar spine (64\% of patients). There was no difference between patients with uncomplicated VO and complicated $\mathrm{VO}$ according to gender, time from symptom onset to hospital admission and MRI established diagnosis, erythrocyte sedimentation rate (ESR) and $\mathrm{C}$-reactive protein (CRP) values, duration of hospitalization, anatomic site of infection and number of vertebral bodies affected. Demographic and clinical data of study patients are presented in Table 1 .

\section{Comorbidities}

Sixty-three (57.3\%) patients had one or more comorbidities. Thirty-seven (33.6\%) patients had a high modified CCI score of 2 or more. There was a statistically significant difference in the frequency of comorbidities between patients with uncomplicated $\mathrm{VO}$ and

Table 1. Demographic and clinical characteristics of 110 patients with vertebral osteomyelitis

\begin{tabular}{|c|c|c|c|}
\hline Characteristic & $\begin{array}{c}\text { Uncomplicated } \\
\text { VO } \\
\mathrm{n}=46\end{array}$ & $\begin{array}{c}\text { Complicated } \\
\text { VO } \\
n=64\end{array}$ & $\mathrm{p}$ value \\
\hline Age (yrs) & $55.0(47.0,66.0)^{*}$ & $\begin{array}{c}62.5(53.0 \\
70.0)^{*}\end{array}$ & 0.038 \\
\hline \multirow{3}{*}{$\begin{array}{l}\text { Days from symptom } \\
\text { onset to: } \\
\\
\text { admission to hospital } \\
\text { MRI established } \\
\text { diagnosis } \\
\end{array}$} & & & \\
\hline & $10.5(4.0,20.0)^{*}$ & $\begin{array}{c}13.5(4.0 \\
30.0)^{*}\end{array}$ & 0.87 \\
\hline & $14.5(10.0,33.0)^{*}$ & $\begin{array}{c}15.0(8.0 \\
30.0)^{*}\end{array}$ & 0.66 \\
\hline $\begin{array}{l}\text { Duration of } \\
\text { hospitalization }\end{array}$ & $34.0(27.0,53.0)^{*}$ & $\begin{array}{c}42.5(29.5 \\
59.0)^{*}\end{array}$ & 0.1 \\
\hline $\begin{array}{l}\text { Laboratory value at } \\
\text { admission: } \\
\\
\text { ESR }(\mathrm{mm} / \mathrm{h}) \\
\text { CRP }(10 \mathrm{mg} / \mathrm{L})\end{array}$ & $\begin{array}{c}64.5(44.0,90.0)^{*} \\
89.5(39.5 \\
184.1)^{*}\end{array}$ & $\begin{array}{c}78.0(50.0 \\
99.0)^{*} \\
102.5(58.4 \\
188.0)^{*} \\
\end{array}$ & $\begin{array}{l}0.12 \\
0.56\end{array}$ \\
\hline $\begin{array}{l}\text { Antimicrobial therapy } \\
\text { duration: } \\
\text { total (weeks) } \\
\text { parenteral (days) }\end{array}$ & $\begin{array}{c}8.5(6.0,10.0)^{*} \\
32.5(22.0,42.0)^{*}\end{array}$ & $\begin{array}{c}9.0(6.0,13.0)^{*} \\
37.0(28.0 \\
54.5)^{*}\end{array}$ & $\begin{array}{c}0.53 \\
0.047\end{array}$ \\
\hline
\end{tabular}

*median (Q1, Q3); VO = vertebral osteomyelitis; MRI = magnetic resonance imaging; $\mathrm{ESR}=$ erythrocyte sedimentation rate; $\mathrm{CRP}=\mathrm{C}$-reactive protein 
Table 2. Presence of comorbidities in patients with vertebral osteomyelitis (VO)

\begin{tabular}{|l|c|c|c|}
\hline Comorbidity & $\begin{array}{c}\text { Uncomplicated VO } \\
\mathrm{n}=46\end{array}$ & $\begin{array}{c}\text { Complicated VO } \\
\mathrm{n}=64\end{array}$ & $\mathrm{p}$ value \\
\hline Degenerative spine disease & $6(13.0 \%)$ & $23(36.0 \%)$ & 0.007 \\
\hline Diabetes mellitus & $5(11.0 \%)$ & $14(22.0 \%)$ & 0.13 \\
\hline Rheumatic inflammatory disease & $5(11.0 \%)$ & $7(11.0 \%)$ & 0.99 \\
\hline Cardiovascular disease & $3(7.0 \%)$ & $7(11.0 \%)$ & 0.43 \\
\hline Liver cirrhosis & $0(0.0 \%)$ & $8(13.0 \%)$ & 0.013 \\
\hline Chronic renal failure & $3(7.0 \%)$ & $7(11.0 \%)$ & 0.2 \\
\hline Malignancy & $1(2.0 \%)$ & $4(6.0 \%)$ & 0.31 \\
\hline Alcohol abuse & $0(0.0 \%)$ & $3(5.0 \%)$ & 0.14 \\
\hline
\end{tabular}

complicated VO according to liver cirrhosis and degenerative spine disease. The frequency of comorbidities detected in patients with $\mathrm{VO}$ is shown in Table 2.

\section{Etiology}

The etiology in $\mathrm{VO}$ was proved in 67 patients (67/110; 61.0\%). Forty-three patients had positive blood cultures $(43 / 97 ; 39.0 \%)$ and 24 patients had positive tissue cultures $(24 / 33 ; 22.0 \%)$. In both groups of patients, Staphylococcus aureus was the most frequently isolated bacterium from blood $(52.0 \%$ in uncomplicated $\mathrm{VO}$ and $47.0 \%$ in complicated VO) and tissue $(78.0 \%$ and $55.0 \%$, respectively) sample cultures. Patients with positive blood culture had a significantly higher mean ESR (78.1 vs. $63.2 \mathrm{~mm} / \mathrm{h}$, $\mathrm{p}=0.024)$ and CRP (178.8 vs. $90.9 \mathrm{mg} / \mathrm{L}, \mathrm{p}<0.001)$, higher fever $(\mathrm{p}<0.001)$ and most commonly high CCI score $(\mathrm{p}=0.019)$.

\section{Magnetic resonance imaging}

The time of radiological diagnosis of $\mathrm{VO}$ from the onset of symptoms ranged from 2 to 90 days, median 15 days (IQR:10-30). Vertebral edema was detected in 108 (98.2\%), discitis in 92 (83.6\%), decreased disc height in 29 (26.4\%), vertebral destruction in 53 (48.2\%) and abscesses in 67 (60.9\%) patients. There were 81 patients with advanced (Figs. 1 and 2) and 19 patients with initial (Fig. 3) MRI findings. Patients

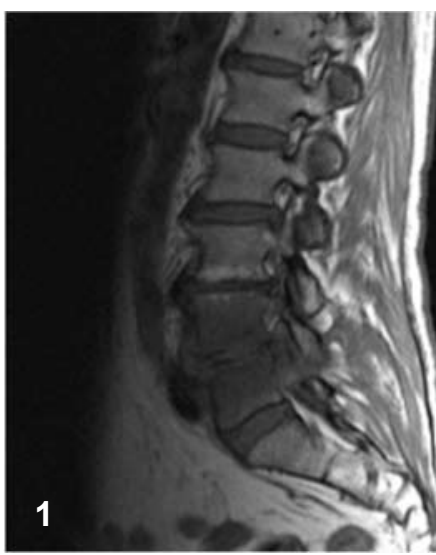

Fig. 1. Sagittal T1WI shows diffuse edema of L4 and L5 vertebral bodies, decreased disc height, and hypointensity of prevertebral and epidural fat due to inflammation.
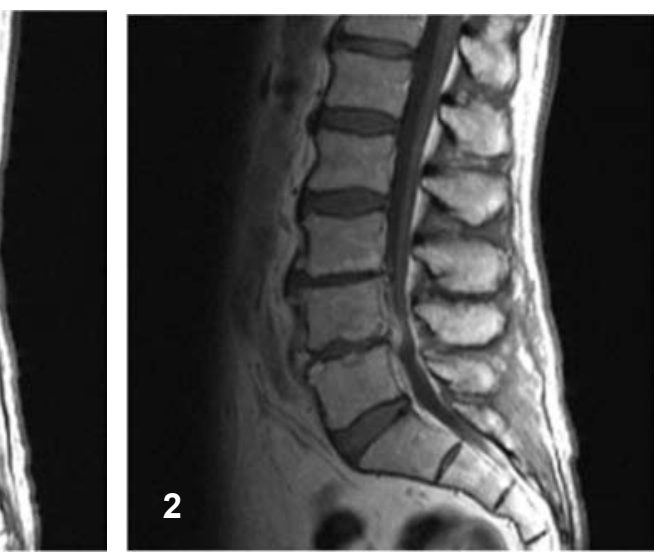

Fig. 2. Contrast-enhanced sagittal T1WI reveals bone marrow hyperemia of L4 and L5 vertebral bodies, peripheral rim enhancement of intervening disc due to abscess formation with endplate erosions, and prevertebral and epidural phlegmon.

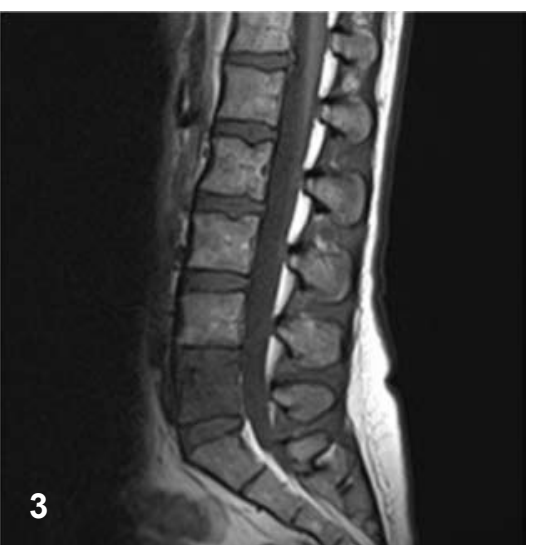

Fig. 3. Sagittal T1WI shows diffuse hypointensity of L5 vertebral body due to edema. Disc height at L4-L5 and L5-S1 is

preserved.

Acta Clin Croat, Vol. 55, No. 1, 2016 
with advanced MRI changes of VO had a modified CCI score of 2 or more $(\mathrm{p}=0.006)$.

\section{Disease outcome}

There were 64 patients with complicated VO out of 110 patients included in the study. They were longer treated with antibiotics parenterally (median days 37.0 vs. 32.5; $\mathrm{p}=0.047)$ and more often surgically $(\mathrm{p}<0.001)$. In these patients, high CCI score was more often observed $(p=0.024)$, as well as liver cirrhosis $(p=0.013)$ and degenerative spine disease $(\mathrm{p}=0.007)$ as comorbidities. Twenty-four (21.8\%) patients had residual neurological deficits or pain; ten of them were treated for less than 8 weeks because therapy was aborted on their demand. Nine (8.2\%) patients died before the end of treatment.

\section{Discussion}

In our study, about one-third of patients with VO were found to have high CCI score. These patients had a significantly higher incidence of advanced changes in MRI findings and more often had complicated VO, compared with patients with low CCI score, probably due to impaired immune response caused by diabetes or chronic renal failure or because of partial modulation of immune response with medications in patients with inflammatory rheumatic diseases. The altered immune system obviously had an impact on the severe disease course in these patients. They had a higher incidence of neurological deficits due to epidural phlegmon and abscess formation according to MRI findings, and consequently the need for surgical treatment and prolonged antimicrobial therapy. Except for degenerative spine disease, the distribution of comorbidities in patients in our study was similar to study results described by Bhavan et al. and Carragee ${ }^{14,15}$. They report on diabetes and chronic renal failure as the leading comorbidities in patients with $\mathrm{VO}$, but did not observe degenerative spine disease as a comorbidity in their patients.

More frequently observed higher values of ESR and CRP, and higher fever in patients with positive blood culture were due to bacteremia in these patients, which led to a more pronounced inflammatory response of the body. Patients with positive blood culture had most commonly high CCI score, which caused bacteremia due to impaired immune system.
Patients with complicated VO more often experienced neurological deficit, but there was no significant difference according to gender, time from symptom onset to hospital admission and MRI established diagnosis, duration of hospitalization, anatomic site of infection and number of affected vertebral bodies between patients with uncomplicated $\mathrm{VO}$ and complicated VO. Generally, most patients were older men, experienced pain and had fever, and one-third of patients had neurological complications, confirming previous findings ${ }^{14,16,17}$. Spinal infection was most frequently located in the lumbar spine and usually affected two neighboring vertebrae and intervening disc, which is similar to other previously conducted studies $^{2,5}$.

The median interval between the onset of symptoms and MRI examination was similar to the results of Carragee, who reports that MRI scans were obtained within less than 3 weeks after symptom onset ${ }^{15}$. The most commonly identified microorganism was $S$. aureus, both in blood cultures and percutaneous bone biopsy cultures, which is consistent with the results reported by Mylona et al., Chen et al., Beronius et al. and Legrand et al. ${ }^{3,18-20}$. There was no difference in total duration of therapy, but patients with complicated VO were longer treated parenterally and more often surgically for epidural phlegmon and abscess formation.

Our study has several limitations, i.e. retrospective design, lack of follow-up MRI and follow-up measurements of laboratory parameters such as ESR and CRP. Routine use of follow-up MRI in patients who have clinical response to therapy is not supported by Kowalski et al. ${ }^{21}$. We agree with Dunbar et al. that follow-up MRI 2-3 weeks after initial MRI seems reasonable in cases where there is clinical evidence for spinal infection but the initial MRI is negative or inconclusive ${ }^{22}$. Instead of follow-up MRI, follow-up measurements of ESR and CRP may be useful to determine the response to antibiotic or surgical treatment.

\section{Conclusion}

Advanced MRI changes and complicated VO were more often observed in patients with high CCI score, probably due to impaired immune system caused by chronic comorbid disease(s) or modulation of immune 
response with medications. High CCI scores were more frequently associated with positive blood cultures due to bacteremia because of impaired immune system. Patients with complicated VO were older, longer treated with antibiotics parenterally and more often surgically treated. Liver cirrhosis and degenerative spine disease, which were more often found in patients with complicated VO, obviously impacted the course of the disease.

\section{References}

1. Grammatico L, Baron S, Rusch E, Lepage B, Surer N, Desenclos JC, et al. Epidemiology of vertebral osteomyelitis (VO) in France: analysis of hospital-discharge data 20022003. Epidemiol Infect. 2008;136:653-60, http://dx.doi. org/10.1017/s0950268807008850.

2. Aagaard T, Roed C, Dragsted C, Skinhoj P. Microbiological and therapeutic challenges in infectious spondylodiscitis: a cohort study of 100 cases, 2006-2011. Scand J Infect Dis. 2013;45:417-24, http://dx.doi.org/10.3109/00365548.2012.7 53160 .

3. Mylona E, Samarkos M, Kakalou E, Fanourgiakis P, Skoutelis A. Pyogenic vertebral osteomyelitis: a systematic review of clinical characteristics. Semin Arthritis Rheum. 2009;39:10-7, doi: 10.1016/j.semarthrit.2008.03.002.

4. Priest DH, Peacock JE Jr. Hematogenous vertebral osteomyelitis due to Staphylococcus aureus in the adult: clinical features and therapeutic outcomes. South Med J. 2005;98:854-62, http://dx.doi.org/10.1097/01.smj.0000168666.98129.33.

5. Capelo J, Carragoso A, Albuquerque C, Mocho ML, CantoMoreira N. Infectious spondylodiscitis: a study of forty-one cases. Acta Reumatol Port. 2007;32:255-62.

6. Butler JS, Shelly MJ, Timlin M, Powderly WG, O’Byrne JM. Nontuberculous pyogenic spinal infection in adults: a 12year experience from a tertiary referral center. Spine (Phila $\mathrm{Pa}$ 1976). 2006;31:2695-700, http://dx.doi.org/10.1097/01. brs.0000244662.78725.37.

7. Mustapić M, Borić I, Lepur D, Zadravec D, Višković K. Sever's disease complicated with osteomyelitis. Acta Clin Croat. 2014;53(2):252-5.

8. Loibl M, Stoyanov L, Doenitz C, Brawanski A, Wiggermann $\mathrm{P}$, Krutsch W, et al. Outcome-related co-factors in 105 cases of vertebral osteomyelitis in a tertiary care hospital. Infection. 2014;42(3):503-10, http://dx.doi.org/10.1007/s15010-0130582-0.

9. Višković K, Miklić D, Lisić M, Đaković Rode O, Mustapić $\mathrm{M}$, Perović $\mathrm{D}$, et al. Imaging techniques and multidiciplinary approach to the vertebral osteomyelitis. Croat J Infect. 2011;31:101-8.

10. Jevtic V. Vertebral infection. Eur Radiol. 2004;14 Suppl 3:4352, http://dx.doi.org/10.1007/s00330-003-2046-x
11. Charlson ME, Pompei P, Ales KL, MacKenzie CR. A new method of classifying prognostic comorbidity in longitudinal studies: development and validation. J Chronic Dis. 1987;40:373-83, http://dx.doi.org/10.1016/0021-9681(87) 90 171-8.

12. Quan H, Li B, Couris CM, Fushimi K, Graham P, Hider P, et al. Updating and validating the Charlson comorbidity index and score for risk adjustment in hospital discharge abstracts using data from 6 countries. Am J Epidemiol. 2011;173:67682, http://dx.doi.org/10.1093/aje/kwq433.

13. Hall WH, Ramachandran R, Narayan S, Jani AB, Vijayakumar S. An electronic application for rapidly calculating Charlson comorbidity score. BMC Cancer. 2004;4:94, http:// dx.doi.org/10.1186/1471-2407-4-94.

14. Bhavan KP, Marschall J, Olsen MA, Fraser VJ, Wright NM, Warren DK. The epidemiology of hematogenous vertebral osteomyelitis: a cohort study in a tertiary care hospital. BMC Infect Dis. 2010;10:158, http://dx.doi.org/10.1186/14712334-10-158.

15. Carragee EJ. Pyogenic vertebral osteomyelitis. J Bone Joint Surg Am. 1997;79:874-80.

16. Karadimas EJ, Bunger C, Lindblad BE, Hansen ES, Hoy $\mathrm{K}$, Helmig P, et al. Spondylodiscitis. A retrospective study of 163 patients. Acta Orthop. 2008;79:650-9, http://dx.doi. org/10.1080/17453670810016678.

17. Yoon SH, Chung SK, Kim KJ, Kim HJ, Jin YJ, Kim HB. Pyogenic vertebral osteomyelitis: identification of microorganism and laboratory markers used to predict clinical outcome. Eur Spine J. 2010;19:575-82, http://dx.doi.org/10.1007/s00586009-1216-1.

18. Chen SH, Chang WN, Lu CH, Chuang YC, Lui CC, Chen $\mathrm{SF}$, et al. The clinical characteristics, therapeutic outcome, and prognostic factors of non-tuberculous bacterial spinal epidural abscess in adults: a hospital-based study. Acta Neurol Taiwan. 2011;20:107-13.

19. Beronius M, Bergman B, Andersson R. Vertebral osteomyelitis in Goteborg, Sweden: a retrospective study of patients during 1990-95. Scand J Infect Dis. 2001;33:527-32, http:// dx.doi.org/10.1080/00365540110026566.

20. Legrand E, Flipo RM, Guggenbuhl P, Masson C, Maillefert JF, Soubrier M, et al. Management of nontuberculous infectious discitis. Treatments used in 110 patients admitted to 12 teaching hospitals in France. Joint Bone Spine. 2001;68:504-9, http://dx.doi.org/10.1016/s1297-319x(01)00315-3.

21. Kowalski TJ, Berbari EF, Huddleston PM, Steckelberg JM, Osmon DR. Do follow-up imaging examinations provide useful prognostic information in patients with spine infection? Clin Infect Dis. 2006;43:172-9, http://dx.doi. org/10.1086/505118.

22. Dunbar JA, Sandoe JA, Rao AS, Crimmins DW, Baig W, Rankine JJ. The MRI appearances of early vertebral osteomyelitis and discitis. Clin Radiol. 2010;65:974-81, http://dx.doi. org/10.1016/j.crad.2010.03.015. 


\section{Sažetak \\ VERTEBRALNI OSTEOMIJELITIS U ODRASLIH BOLESNIKA - KARAKTERISTIKE I ISHOD}

\section{Mustapić, K. Višković, I. Borić, D. Marjan, D. Zadravec i J. Begovac}

Ciljevi istraživanja su bili prikazati karakteristike i ishod vertebralnog osteomijelitisa (VO) u odraslih bolesnika. Radi se o retrospektivnoj studiji u koju je bilo uključeno 110 bolesnika s VO koji su hospitalizirani u petogodišnjem razdoblju. Bolesnici su podijeljeni u skupinu s nekompliciranim i skupinu s kompliciranim VO. Svi bolesnici su imali nalaze laboratorijskih pretraga i MR pregled kralježnice. Bolesnici s kompliciranim VO su bili značajno stariji $(\mathrm{p}=0,038)$, duže su parenteralno liječeni antibioticima $(p=0,047)$ i češće su kirurški liječeni $(\mathrm{p}<0,001)$. $U$ istih bolesnika su češće bili zastupljeni viši stupanj komorbiditeta po Charlsonu (engl. Charlson comorbidity index score, CCI score) $(\mathrm{p}=0,024)$, ciroza jetre $(\mathrm{p}=0,013)$ i degenerativna bolest kralježnice $(\mathrm{p}=0,007)$ za razliku od bolesnika s nekompliciranim VO. Bolesnici s uznapredovalim MR promjenama su češće imali viši zbir CCI, 2 ili više $(\mathrm{p}=0,006)$ te učestalije neurološke ispade $(\mathrm{p}=0,021)$. Staphylococcus aureus je najčešće izolirana bakterija iz krvi i tkiva. Uznapredovale MR promjene i komplicirani VO su češće bili zastupljeni u bolesnika koji su imali viši zbir CCI, najvjerojatnije zbog oštećenja imunog sustava uslijed komorbiditeta ili promjene imunog odgovora lijekovima. Viši zbir CCI je češće bio udružen s pozitivnim hemokulturama uslijed bakterijemije zbog oštećenja imuniteta. Bolesnici s kompliciranim VO su duže parenteralno liječeni antibioticima zbog učestalijih flegmona ili apscesa. Ciroza jetre i degenerativna bolest kralježnice koji su kao komorbiditeti bili učestaliji u bolesnika s kompliciranim VO najvjerojatnije su utjecali na tijek bolesti.

Ključne riječi: Osteomijelitis kralježnice; Magnetska rezonancija, snimanje; Komorbiditet; Ishod zdravstvene skrbi, ocjena; Odrasla osoba 